\title{
I mpact of pesticide Rogor toxicity on serum phosphomonoesterase levels of freshwater catfish Clarias batrachus
}

\author{
Sudhish Chandra \\ P.G. Department of Zoology, B.S.N.V. College, Lucknow - 226001, INDIA \\ E-mail: sudhish1953@gmail.com \\ Received: December 13, 2012; Revised received:D ecember 26, 2012;Accepted:J anuary 27, 2013
}

Abstract: The exposure of pesticide Rogor had significantly altered serum alkaline and acid phosphatase activities in freshwater catfish, Clarias batrachus at different concentrations and duration under static conditions. However, the intensity of activity of both the enzymes were interestingly different. The fish elicited marked behavioral changes with increasing concentrations and exposure duration. The rising trend in enzyme levels which mediate membrane transport mechanism and biosynthesis of macromolecules, have been correlated with the induction and leakage of respective enzymes from liver following membrane damage and necrosis due to pesticide toxicity.

Keywords: Catfish, Rogor pesticide, Serum phosphatase, Toxicity

\section{INTRODUCTION}

Varied pollutants from industries and agricultural processes have contributed to contamination of freshwater systems, making adverse impact on aquatic biota. Among freshwater inhabitants fishes are frequently prone and economically the most important that suffer from exposure to different toxicants directly or indirectly in various ways, leading to major decline in their population and human health (Wang, 2002, Kalita et al., 2003; Deutremepuits et al., 2004; Shukla et al., 2007; Agtas et al., 2007; Yoon et al., 2008; Despande et al., 2011). The degree of toxicity due to pollutants could be predicted by applying short as well as long term tests, using fish as a bioindicator (Mullick and Konar, 1995; Athikesawan et al., 2006). Alterations observed in physiological and biochemical parameters of toxicant treated fishes are sensitive index of the changes due to pesticide toxicity and can constitute important diagnostic tool in water quality assessment in the field of environmental toxicity.

Phosphatases are an important and critical enzymes in the biological system responsible for detoxification processes, metabolism and biosynthesis of energetic macromolecules for different functions. It's clinical value have been correlated with anaemia, malnutrition, hyperglycemia, skeletal and liver disorders (Bell et al., 1980). Blood being an integrated and enevitable part of every tissue, piscine haematology becomes useful in assessing the health and general condition of the animal subjected to changing ecophysiological situations (Kori Siakpera and Ubogu, 2008). The present paper embodies observations on toxic effects of pesticide Rogor on serum alkaline and acid phosphatase level of freshwater catfish Clarias batrachus, an active and hardy fish of economic importance due to its food and medicinal value.

\section{MATERIALS AND METHODS}

Live Clarias batrachus were collected from local resources with the help of fishermen, transported to laboratory and treated with $\mathrm{KMnO}_{4}(2 \mathrm{mg} / \mathrm{l})$. Apparently healthy looking fishes of weight range 180-200 grams were selected, transferred to glass aquaria and acclimatized for seven days under standard laboratory conditions as described earlier (Chandra, 2008). They were fed properly and then starved for 24 hours before the experiment. Fish from the same group kept under normal conditions were used as control. Static bioassay tests were performed as given by Doudoroff et al. (1951) and APHA (2005). Four different concentrations of pesticide Rogor $\left(\mathrm{C}_{5} \mathrm{H}_{12} \mathrm{O}_{3} \mathrm{NPS}_{2}\right.$ formulation liquid 30EC) were selected for the experiment on the basis of $80-100 \%$ survival of fishes (Table 1). Fish were exposed to different concentrations of pesticide from 24 to 96 hours depending upon their survival at the particular concentration. The control and pesticide exposed fishes from each concentration were taken out every 24 hours interval, were washed with distilled water, blotted dry and blood was collected in a clean dry tube, after severing off its caudal peduncle. Blood was allowed to clot at room temperature for 15 minutes, then centrifuged and clear serum decanted in a vial, kept in refrigerator until analyzed. Fish were carefully examined for any visible disease or parasitic infection. Biochemical estimation of serum alkaline and acid phosphatase were performed following method of King and Wootton (1959), using Bausch and 
Lomb spectronic-20 spectrophotometer at $620 \mu \mathrm{m}$. The physico-chemical characteristics of dechlorinated tap water during the experiment were temperature $19-20^{\circ} \mathrm{C}$; $\mathrm{pH}$ 7.6-7.8; dissolved oxygen $6.0-7.5 \mathrm{mg} / \mathrm{l}$; total alkalinity $110-118 \mathrm{mg} / \mathrm{l}$ and total hardness $120-125 \mathrm{mg} / 1$.

\section{RESULTS}

A comparative data of serum alkaline phosphatase and acid phosphatase levels in control and pesticide exposed fish upto 96 hours at different concentrations have been presented in Table 2. Significant increase in activity of both phosphomonoesterases were observed due to rogor toxicity in $\mathrm{C}$. batrachus at different concentrations and exposure periods. At $7.50 \mathrm{mg} / \mathrm{l}$ pesticide exposure, serum alkaline phosphatase levels increased by $38.80 \%$, $36.05 \%, 16.29 \%$ and $9.96 \%$ after $24,48,72$ and 96 hours respectively. At $8.25 \mathrm{mg} / \mathrm{l}$ concentration the enzyme level rose by $39.55 \%, 29.38 \%$ and $12.09 \%$ after 24,48 and 72 hours respectively above control. At $8.75 \mathrm{mg} / \mathrm{l}$ pesticide exposure the level elevated by $44.55 \%$ and $23.58 \%$ after 24 and 48 hours versus control and fish did not survive beyond that. At $9.50 \mathrm{mg} / \mathrm{l}$ rogor exposure serum alkaline phosphatase level increased $31.80 \%$ above control after 24 hours and the dose proved lethal. The enzyme level revealed maximal escalation during initial 24 hours exposure at all concentrations and then gradually decreased but remained above control level. The difference between initial and terminal increase in enzyme level at $7.50 \mathrm{mg} / 1,8.25 \mathrm{mg} / \mathrm{l}$ and $8.75 \mathrm{mg} / \mathrm{l}$ pesticide exposure were gradual denoting $36.24 \%, 31.23 \%$ and $27.44 \%$ respectively.

Impact of rogor toxicity on serum acid phosphatase level of $\mathrm{C}$. batrachus was observed to be directly proportional to exposure period during their absolute percentage survival at different pesticide concentrations. The enzyme level rose $11.89 \%, 29.56 \%, 36.55 \%$ and $20.11 \%$ after 24 , 48,72 and 96 hours of exposure respectively at $7.50 \mathrm{mg} / \mathrm{l}$ pesticide concentration. Serum acid phosphatase activity enhanced by $15.24 \%, 24.98 \%$ and $15.24 \%$ after 24,48 and 72 hours respectively at $8.25 \mathrm{mg} / \mathrm{l}$ concentration. Enzyme level indicated $17.78 \%$ and $13.27 \%$ gain after 24 and 48 hours duration at $8.75 \mathrm{mg} / \mathrm{l}$ pesticide concentration. At $9.50 \mathrm{mg} / \mathrm{l}$ rogor exposure acid phosphatase activity was $26.78 \%$ higher as compared to control during 24 hours, beyond that fish could not survive. The fish elicited marked behavioural changes during the experiment. They appeared restless, hyperactive showing erratic movements, rapid opercular beats, surfacing, loss of balance, copious mucus secretion, pale colouration followed by calmness an finally death.

\section{DISCUSSION}

Biochemical parameters are sensitive indices of structural and functional status of body organs, useful in understanding metabolic alterations and constitute an
Table 1. Percentage survival of fish during the expriment on exposure to pesticide Rogor.

\begin{tabular}{lcccc}
\hline Rogor conc. & \multicolumn{4}{c}{ Time of exposure in hours } \\
\cline { 2 - 5 } (mg/l) & 24 & 48 & 72 & 96 \\
\hline Control (0\%) & $100 \%$ & $100 \%$ & $100 \%$ & $100 \%$ \\
7.50 & $100 \%$ & $100 \%$ & $100 \%$ & $60 \%$ \\
8.25 & $100 \%$ & $100 \%$ & $40 \%$ & \\
8.75 & $100 \%$ & $100 \%$ & $20 \%$ & \\
9.50 & $100 \%$ & $10 \%$ & & \\
\hline
\end{tabular}

important diagnostic tool in toxicological studies and investigating diseases (Edsall, 1999; Shaikh and Negi, 2004). Phosphatases being important lysosomal brush border enzymes which catalyzes the splitting of phosphoric acid from certain phosphate esters and generally located on absorptive and secretory surfaces of cells, mediating membrane transport mechanism, are thus early indicators of environmental degradation. Any interference in enzyme activity lead to biochemical impairment, cellular dysfunction, metabolic and physiological activities of the fish. Abnormal behavioral patterns, exhibited by $\mathrm{C}$. batrachus during the experiment indicated its efforts to ward off the situation and were identical to that reported in fishes subjected to different pesticides by Tandon and Dubey, 1983; Tripathi and Shukla, 1988; Lata et al., 2001 and Chandra, 2008. Hyperphosphatemia has been noticed in fish after exposure to various toxicants (Gupta et al., 1975; Singh et al., 1996; Yogesh and Saxena, 1999; Singh and Saxena, 2001). Rogor exposure had significantly increased serum alkaline and acid phosphatases in these experiments at all concentrations, the action and the intensity of reaction of both the enzymes were interestingly however, different. Serum alkaline phosphatase level increased sharply during initial periods of exposure, followed by gradual decrease with increasing exposure duration at all concentrations till the fish survived, whereas the acid phosphatase level elevated gradually with increasing exposure period, till the fish was active, then repressed. This clearly elicited different mode of action of alkaline and acid phosphatase to coordinate with impairing cellular, metabolic and physiological activities of fish due to harmful effects following acute and subacute treatment with rogor. Gills being most sensitive to changes in surrounding water become primary target of the contaminants, adversely affecting gas exchange and ionic regulation (Camargo and Martinez, 2007) leading to physiological stress suggesting prevalence of hypoxic environment in the blood of the fish. Biochemical changes have been reported due to shift in respiratory metabolism caused by pesticide in the ambient environment and utilization of organic reserves for energy liberation, needed to compensate the body stress and it was evident in $C$. batrachus following rogor toxicity. Linear 
Table 2. Serum alkaline and acid phosphatase levels of $C$. batrachus following pesticide Rogor toxicity.

\begin{tabular}{|c|c|c|c|c|}
\hline \multirow{2}{*}{$\begin{array}{l}\text { Rogor conc. } \\
(\mathrm{mg} / \mathrm{l})\end{array}$} & \multicolumn{4}{|c|}{ Time of exposure in hours } \\
\hline & 24 & 48 & 72 & 96 \\
\hline & \multicolumn{4}{|c|}{ Serum alkaline phosphatase (KA units/100ml) } \\
\hline & \multicolumn{4}{|c|}{ Mean \pm SD } \\
\hline & \multicolumn{4}{|c|}{ Control-5.96+0.42 } \\
\hline 7.50 & $9.74 \pm 1.83$ & $9.32+0.41$ & $7.12+0.60$ & $6.60 \pm 0.82$ \\
\hline 8.25 & $9.86 \pm 1.60$ & $8.44 \pm 1.01$ & $6.78 \pm 0.72$ & \\
\hline 8.75 & $10.75 \pm 0.74$ & $7.80 \pm 0.73$ & & \\
\hline \multirow[t]{3}{*}{9.50} & $8.74+0.78$ & & & \\
\hline & \multicolumn{4}{|c|}{ Serum acid phosphatase (KA units/100ml) } \\
\hline & \multicolumn{4}{|c|}{ Control-11.56+1.87 } \\
\hline 7.50 & $13.12 \pm 0.92$ & $16.42+2.09$ & $18.22 \pm 1.40$ & $14.47 \pm 1.26$ \\
\hline 8.25 & $13.64+1.24$ & $15.42+2.14$ & $13.64+2.02$ & \\
\hline 8.75 & $14.06 \pm 2.85$ & $13.33 \pm 2.84$ & & \\
\hline 9.50 & $13.86 \pm 2.66$ & & & \\
\hline
\end{tabular}

No. of observations 10 in each experiment

increase in serum phosphatase have been reported in C. batrachus following asphyxiation and the balance in acid and alkaline phosphatase level appeared to be nearly adjusted by hormonal machinery which comes to play under such situation of stress (Chandra, 1994; Nath et al., 2000; Verma and Nath, 2004). Similar observations have been reported in different biochemical parameters of fish following exposure to different pesticides by Singh and Srivastava, 1998; Nath, 2003; Padmini et al., 2004; Thosar and Lonker, 2004; Deshmukh and Sonawane, 2007 and Chandra, 2007. Biochemical alterations clearly indicated shifting of metabolic reactions to utilize organic reserve for energy to accommodate, adapt and resist with toxic stress, till it was lethal. Long standing exposure to organosphosphate compounds may produce adaptive mechanism expressed by tendency towards an increase of synthesis of various serum enzymes (Janardan and Sisodia, 1990). Rising trend in serum acid and alkaline phosphatase levels have also been related due to induction and leakage of the respective enzymes following liver necrosis (Foster, 1980; Tomer et al., 1995; Rahman et al., 2000), indicating their role as bioindicator of membrane damage and tissue necrosis, which can be widely interpreted to predict and detect early warning of pesticide toxicity in aquatic environment and as a useful tool to save deterioting fish population and their biodiversity in its habitat.

\section{REFERENCES}

Agtas, S., Huseyin, G. and Suleyman, G. (2007) Concentrations of heavy metals in water and chub, Leuciscus cephalus from the river Yildiz, Turkey, J. Environ. Biol., 28:845-849.

APHA (2005). Standard methods for the examination of water and wastewater (21st Edn.). Washington, D.C.: American Public Health Association.

Athikesawan, S., Vincent, S. and Velmurugan, B.(2006).
Investigation of acute toxicity of zinc sulphate in silver carp. Hypophthalmichthys molitrix. Aquacult. 7:331-333.

Bell, G.H., Smith, D.E. and Patterson, C.R.(1980). Text book of Physiology. Churchill, Livingston, London.

Camargo, M.M. and Martinez, C.B.(2007). Histopathology of gills, kidney and liver of a neotropical fish caged in an urban stream. Neotrop. Ichthyol., 5:327-336.

Chandra, S. (1994). Effect of asphyxiation on serum alkaline and acid phosphatase levels of freshwater catfish Clarias batrachus. Him. J. Environ. Zool., 8:9-12.

Chandra, S. (2007). Pesticide induced changes in the activity of transminases in tissues of freshwater catfish, Clarias batrachus. Rec. Adv. Fish E col. Limnol. Ecocons., 7:143149.

Chandra, S. (2008). Toxic effect of Malathion on acetyl cholinesterase activity of liver, brain and gills of freshwater catfish H eteropneustes fossilis. E nviron. Conser. J ., 9:47-52.

Deshmukh, D.R. and Sonawane, S.R. (2007). Effect of long term exposure to endosulfan on blood cell count in Channa gachua. J . Indian Fish. Assoc., 34:83-85

Deshpande, A. S., Zade, S. B. and Sitre, S.R.(2011). Histopathological changes in the gill architecture of Labeo rohita from the pond adjuscent to thermal power station, Koradi, Nagpur, India, J . A ppl. \& Nat.Sci., 3:284-286.

Deutremepuits, C., Paris - Palacios, S., Betoulle, S. and Vernet, G.(2004). Modulation in hepatic and head kidney parameters of carp (Cyprinus carpio) induced by copper and chitosan. Comp. Biochem. Physiol. C. Toxicol. Pharmacol., 137:325-333.

Doudoroff, P. A., Burdick, B. G., Galtsoff, P. S., Hart, W. B. Patrick, R., Strong, E.R. and Von Horn, W.M. (1951). Bioassay methods for the evaluation of acute toxicity of industrial wastes to fish. Sewage Ind. Wastes., 23:13801397.

Edsall, C. C.(1999). A blood chemistry profile for lake trout. J. Ag. Anim. HIth., 11:81-86.

Foster, R.L. (1980). The nature of Enzymology. Croom Helm Applied Biol. Series-275-312.

Gupta, P. K., Gupta, R. C. and Kohli, J. D. (1975). Recent Pesticides - A review. Pesticides, 9:15-21. 
Janardan, A. and Sisodia, P.(1990). Monocrotophos: short term toxicity in rats. Bull. Env. Contam. Toxicol., 44:230-239.

Kalita, J., Baruah, B. K., Chaudhary, M., Saikia, S., Choudhury, S. K. and Das, M.(2003). Study on the effect of water pollutants on carbohydrate profile in fish, Heteropneustes fossilis, Aquacult., 4:237-340.

King, E. J. and Wootton, I. D. P. (1959). Microanalysis in medical Biochemistry, J. and A. churchill, London.

Kori-Siakpera, O. and Ubogu, E.O.(2008). Sublethal haematological effects of zinc on the freshwater fish, Heteroclarias sp. Afr. J. Biotech., 7:2068-2073.

Lata, S., Gopal, K. and Singh, N.N. (2001). Toxicological evaluations and morphological studies in a catfish Clarias batrachus exposed to carbaryl and carbofuran. J . E cophysiol. Occup. HIth., 1:121-130.

Mullick, S. and Konar, S.K.(1995). Impact of estimated safe levels of zinc,copper, iron and lead mixture on aquatic ecosystem. Environ. Ecol., 13:338-394.

Nath, A. (2003). Bioaccumulation of various pesticides in fish muscle.] .Ecophysiol. Occup. H Ith., 3:40-46.

Nath, A., Chand, GB., Sinha, A. and Singh, A.(2000). Hormonal imbalance and related ultrastructural changes in the testis of Rogor treated Clarias batrachus. J . Inland Fish.Soc. India, 30:87-93.

Padmini, E., Thendral Hepsibha, B. and Santhalin Shellomith, A.S. (2004). Lipid alterations as stress markers in grey mullet Mugil cephalus caused by industrial effluents in Ennore eustury. Aquacult., 5:115-118.

Rahman, M. F., Siddiqui, M. K. J. and Jamil, K.(2000). Acid and alkaline phosphatase activities in a novel phosphorothionate (RPR-II) treated male and female rats. Evidence of dose and time dependent response. D rug. Chem. Toxicol., 23:497-509.

Shaikh, N. and Negi, S.G. (2004). Effects of Rogor on protein and glycogen in the muscle of freshwater fish Lepidocephalichthys thermalis. Aquacult., 5: 119.121.

Shukla, N.P., Srivastava, A.K. and Purvar, A (2007). The effect of various pollutants on fishes. Flora $\&$ F auna, 13:165-179.
Singh, V.K. and Saxena, P.N. (2001). Effect of cybil (Cypermethrin-25EC) and Cybil - sevin (Carbaryl 50EC) combination on liver and serum phosphatases in wistar albino rats. J. Ecophysiol. O ccup. HIth., 1:229-234.

Singh, N.N. and Srivastava, A.K. (1998), Formothion induced biochemical changes in blood and tissues of freshwater catfish Heteropneustes fossilis. M alys. Appl. Biol., 27:39-43.

Singh, N. N., Das, V. K. and Singh, S. (1996). Effect of aldrin on protein carbohydrate, and ionic metabolism of a freshwater catfish Heteropnustes fossilis, Bull. Env. Cont. Toxicol., 57:204-210.

Tandon, R.S. and Dubey, A. (1983). Toxic effects of two organophosphorus pesticides on fructose-1,6 disphosphate aldolase activity of brain and gills of freshwater fish Clarias batrachus. Environ. Pollut., 31:1-7.

Thosar, M.R. and Lonker, A. N.(2004). Respiratory response of male fish Labestes reticulatus exposed to sublethal concentration of insecticide Metasystox. J. Ecophysiol. Occup. HIth., 4:62-67.

Tomar, M.S. and Dhanotiya, R. S., Shilaskar, D.V. and Dixit, N.K. (1995). Effect of Malathion on enzymes of goat liver and serum. J. Environ. Biol., 16:151-155.

Tripathi, G. and Shukla, S. P. (1988). Toxicity bioassay of technical and commercial formulation of carbaryl to the freshwater catfish, Clarias batrachus. E cotox. E nviron. Safe. 15:227-281.

Verma, P. and Nath, A. (2004). Correlation between ultrastructural changes and thyroid hormonal imbalance in ovary of air breathing fish during induced toxicity. J. Ecophysiol 0 ccup. HIth., 4:207-215.

Wang, W.X. (2002). Interaction of trace metals and different marine food chains. M ar. E col. P rog. Ser., 243: 295-309.

Yogesh, K.G. and Saxena, P.N. (1999). Effect of Mexacarbate on liver and serum phosphatase of Passer domesticus. Pavo, 37: 109-118.

Yoon, S., Sang Seop, H. and Rana, S.V.S. (2008). Molecular markers of heavy metal toxicity - A new paradigm for health, risk assessment. J. Environ. Biol., 29: 1-14. 